\title{
Relationship between Emotional Intelligence and Communication Skills of Healthcare Workers
}

\section{Sağlık Çalışanlarının Duygusal Zekâ ve İletişim Becerileri Arasındaki İlişki}

Necmettin GÜL ${ }^{1}$

\begin{abstract}
Purpose: The importance of health workers has revealed more with the epidemic process. This process also required healthcare workers to be in contact with more individuals than in the normal process This study aims to reveal the relationship between emotional intelligence and communication skills of healthcare workers.
\end{abstract}

Design/Methodology: 150 questionnaires have been applied to healthcare workers by using the "Emotional Intelligence Scale" of Wong and Law (2002) and "Communication Skills Scale-Adult Form” of Korkut-Owenand Demirbaş-Çelik, (2017).

Findings:. Reliability, frequency, correlation, and regression analyses have been made via the SPSS statistical program and the outcomes have been interpreted. It is clear that there is a positive and significant relationship between employees' communication skills and perception of emotional intelligence $(r=0.823, p<0.01)$ via the Pearson correlation analysis. It is also concluded that there is an effect of emotional intelligence on communication skills $(p<0.05$, beta $=.823$ )

Limitations: The limitations of the study are that the sample only consists of the employees of a private hospital operating in the Mediterranean Region and only includes healthcare professionals.

Originality/Value: A study examining the relationship between emotional intelligence and communication skills of individuals during the recent pandemic process has not been reached. In this respect, the study has an original value in that the emotional intelligence levels of the employees focus on their communication skills in a difficult period such as the pandemic. In addition, severa suggestions and implications are also offered for hospital administrators and policymakers in this study.

Keywords: Emotional Intelligence, Communication,

Communication Skills

\section{$\ddot{\mathbf{O}}$}

Amaç: Yaşanılan salgın süreci sağlık çalıșanlarının önemi daha çok ortaya çıkarmaktadır. Bu süreç aynı zamanda sağlık çalışanlarının normal süreçten daha fazla sayıda birey ile iletişim halinde olmalarını gerektirmektedir. $\mathrm{Bu}$ araștırmanın amacı, sağlık çalışanlarının duygusal zekâ ve iletişim becerileri arasındaki ilişkiyi oraya koymaktır.

Tasarım/Yöntem: Wong ve Law (2002)'un "Duygusal Zeka" ölçeği ile Korkut-Owen ve Demirbaş-Çelik (2017)'in "İletişim Becerileri Ölçeği-Yetişkin Formu” ölçeği kullanılarak sağlık çalışanlarına 150 adet anket uygulanmıştır.

Bulgular: Calıșmada SPSS istatistik programı aracılığı ile elde edilen verilere güvenirlik, frekans, korelasyon ve regresyon analizleri uygulanmıştır. Pearson Korelasyon analizi ile duygusal zeka algısının $(\mathrm{r}=0.823, \mathrm{p}<0.01)$ çalıșanların iletișim becerileri ile pozitif ve anlamlı bir ilişkiye sahip olduğu, bununla birlikte duygusal zekanın iletișim becerileri üzerinde pozitif yönde bir etkisi $(\mathrm{p}<0.05$, beta $=.823)$ olduğu sonucuna ulaşılmıştır

Sınırlılıklar: Calıșmanın örnekleminin sadece Akdeniz Bölgesinde faaliyet gösteren bir özel hastane çalışanlarından oluşması ve sadece sağlık çalışanlarını kapsaması araştırmanın sınırlılıklarını olușturmaktadır.

Özgünlük/Değer: Son dönemlerde yaşanan salgın sürecinde bireylerin duygusal zekâ ve iletișim becerileri arasındaki ilișkiyi inceleyen bir çalışmaya ulaşılamamıştır. $\mathrm{Bu}$ doğrultuda çalışma salgın gibi bir zorlu süreçte çalıșanların duygusal zekâ düzeylerinin iletișim becerilerine odaklanması konusunda özgün bir özellik taşımaktadır. Ayrıca bu çalışmada hastane yöneticilerine ve politika yapıcılara yönelik çeşitli öneriler ve çıkarımlar da sunulmaktadır.

Anahtar Kelimeler: Duygusal Zekâ, İletişim, İletişim Becerileri

\footnotetext{
${ }^{1}$ Assist. Prof. Dr., Kahramanmaraş Sütçü İmam University, Faculty of Economics and Administrative Sciences, Social
} Service Department, ngul@ksu.edu.tr, ORCID: 0000-0001-9497-5674 


\section{INTRODUCTION}

In recent years, emotional intelligence and its importance have been accepted by businesses and followed with increasing interest. Likewise, effective communication skills and the issue of increasing these skills are another important issues emphasized by businesses. The health sector, where communication is intense, has an important place among these enterprises (Barut, 2015).

People interact with and affect their environments and are also affected by their environments through communication. Therefore, communication is very important for people who are social beings. Having emotional self-awareness, achievement orientation, social skills, empathy and emotional self-control can be described as emotional intelligence and has an important place in adopting communication skills to maintain a healthy business and social life.

Using emotional intelligence and communication skills is also an important key to success in working life. When emotional intelligence is considered from the point of view of healthcare workers; To establish a good relationship with patients, employees are expected to be individuals who can be aware of and manage their emotions, empathize, have social competence, motivate themselves and patients and communicate effectively, and as a result, have developed emotional intelligence skills (Türken et al., 2016). In addition, the importance of communication skills has increased due to the intense working hours and intense stress of healthcare workers during the covid 19 process.

As it is impossible for us to lead a life without emotions, our emotions have a positive or negative impact on the process of our communication with individuals in our environment. Knowing one's emotions and keeping them under control are believed to allow individuals to have a more successful communication process. This study aims to investigate the relationship between emotional intelligence and communication skills.

\section{CONCEPTUAL FRAMEWORK}

\subsection{Emotional Intelligence}

Emotional intelligence has been a popular field of behavioural research that attracts the interest of the academic world, the public and the business world (Anand \& Udayasuri, 2010) and in recent years it has received a great deal of scientific interest and become a trending research subject in the literature. Specifically, after the studies proved that emotions contributed to thinking, research about emotional intelligence increased (Aslan \& Özata, 2008). Emotional intelligence is conceptualized as individuals' proper awareness of their feelings (Swarnalatha \& Sureshkrishna, 2013). As a leadership quality, emotional intelligence competency becomes even more important in enabling individuals to be socially active, and therefore more capable of achieving successful collaborative outcomes (Cole et al., 2016). Goleman (1998) defines emotional intelligence as the ability for recognizing our feelings and those of others to motivate ourselves and manage our emotions and our relationships with others.

Emotional intelligence is a kind of social intelligence that can be described as the ability to observe one's own and others' emotions, distinguish between them, and use the information to guide one's thinking and actions accordingly (Salovey \& Mayer, 1990). Goleman (1995) defines emotional intelligence as the "ability to motivate oneself and persist in the face of frustrations, to control impulse and delay gratification, to regulate one's moods and keep distressed from swamping the ability to think, to empathize and to hope". Weisinger (1998) makes a simpler description focusing on the communicative dimension of emotional intelligence, defining it as "the intelligent use of emotions". Tuğrul (1999) defines emotional intelligence as "the ability of recognizing one's own emotions, coping with emotions, self-motivation, empathy and managing relationships".

Emotional intelligence is also a very important concept for success in business life. A manager keeps the spirit of his/her team alive with his/her emotional intelligence and contributes to increasing the business performance of his/her employees by motivating them. Employees with high emotional intelligence tend to increase their loyalty to the institution they work for, provide maximum benefit to the institution, and continuously invest in their career due to positive emotions they feel for the institution. On the other hand, managers with low emotional intelligence destroy team spirit by making 
employees feel that they just work for a fee and should only do their jobs which decreases their work performance and motivation by preventing their communication with each other, and thus reducing the productivity and efficiency of the institution (Özbek \& Boztepe, 2017). Emotional intelligence is also of great importance in terms of employee retention, organizational communication, workplace security, customer satisfaction, quality, employee turnover, and rapid adaptation of the institution to changes (Codier et al., 2013).

Emotional Intelligence, a book published by Goleman in 1995, has played a great role in the recent emphasis on the concept of emotional intelligence in our modern world. The emotional intelligence model that Goleman developed under the dimension of emotional intelligence and considered as a mixed model like Bar-On was grouped under five categories: Being aware of one's own emotions (self-awareness), controlling one's own emotions (self-regulation), motivating oneself (self-motivation), empathy, and social skills (Rahim et al., 2002). These are accepted as the components of emotional intelligence in the literature.

\subsection{Communication Skills}

Communication is a process in which the meanings of thoughts, ideas, knowledge, and culture are conveyed using symbols (Tutar \& Yilmaz, 2003). Communication, one of the most important needs in human life, is a process of sharing emotions, thoughts, attitudes and behaviours. Symbols and signs that are used in this process may be in written, oral, or non-verbal forms. Sharing various events, situations, information, ideas, or opinions does not only require transferring them to the other party but also receiving and understanding feedback from the other party. This is because both the sender and the receiver must perceive, understand, and interpret the same picture, symbol, shape, etc. to communicate with each other in this process (Şen \& Demir, 2009). Although communication skills have a high impact on communication success, they can be defined as sensitivity to verbal and nonverbal messages, listening and reacting to them effectively (Korkut, 2004).

The conditions for communication, which is effective in interpersonal communication and in parallel with emotional intelligence abilities, are to understand the scope and communication of individuals' multi-faceted emotions about a task, relationship, and disagreement; to make a relatively accurate deduction of emotions of others by using both verbal and non-verbal clues; to have access to the dictionary of emotionally charged words and metaphors; to empathize with the problems of others; to have awareness of coping with difficult conditions that affect the results; and to understand and accept that one's on-going verbal and non-verbal behaviours affect other people's reactions towards oneself (Saarni, 2001). Our emotions and thoughts are positively or negatively reflected in the process of communication we have established in our environment.

An ability to manage self-emotions will help individuals to have healthy relationships in their social and professional lives. Managing self-emotions will provide individuals with an ability to use their intellectual intelligence in the face of difficult situations and to control the situations in working life where emotions are intensely experienced. As a result of good management of emotional accumulation, the communication process of an individual will affect the adoption of a conciliatory approach rather than the conception of conflict, and the orientation of the communication process in this way. In this respect, such an action presumably will play a considerably active role in the communication skills of individuals (Pelit et al., 2018). In addition, the emotion management of individuals is more successful with high communication skills.

\subsection{Relationship between Emotional Intelligence and Communication Skills}

There are several studies, made before covid 19, on the relationship between emotional intelligence and communication skills. In the study by Yousefi (2006), the data illustrated that emotional intelligence was positively associated with communication skills. The study also showed that gender differences in emotional intelligence and communication skills were not significant. Çetinkaya and Alparslan (2011) stated that the impact of empathic sensitivity, one of the subdimensions of emotional intelligence, on communication skills was statistically significant. Jorfi (2012) conducted a study with 145 employees of educational institutions in Iran that revealed emotional intelligence had a significant impact on communication skills and stated that managers should pay attention to these two issues. Petrovici and Dobrescu (2014) reported that women has a 
higher level of emotional intelligence than men. Jadhav and Gupta (2014) explained the benefits of the relationship between emotional intelligence and communication skills. Barut (2015) reported a significant relationship between emotional intelligence, communication skills, and organizational culture, and found a mediating role of organizational culture in this relationship. Taşliyan et al. (2017) pointed a significant relationship between emotional intelligence, communication skills, and academic success. They also found that emotional management, empathic sensitivity, and the positive use of emotions from emotional intelligence dimensions had a statistically significant effect on communication skills. Gül (2017) found a significant relationship between communication skills and all dimensions consisting of total emotional intelligence. Hendon et al. (2017) determined a significant and positive relationship between emotional intelligence and communication skills. Büyükbeşe et al. (2017) concluded that emotional intelligence has a positive impact on communication skills and individual innovation. Ghasemi et al. (2018) concluded that emotional intelligence and communication skills were closely correlated. In a similar vein, Amini et al. (2018) determined a significant relationship between emotional intelligence and communication skills. Lou and Zhang (2018) revealed statistically significant differences in listening, speaking ability, and relationship establishment dimensions between different genders, and determined a positive correlation between communication skills and emotional intelligence of medical students.

People are greatly impacted by others in terms of having success and happiness in every aspect of life. People who establish good relationships with others are more profitable and happier in every period of their lives. Building good relations with others may refer to (or imply) high emotional intelligence

Emotional intelligence is important for building relationships with other individuals, and communication, which is important for people, starts within the period when individuals try to understand self-emotions. Success in business and social life requires having effective communication skills. Effective communication starts with an individual's self-recognition. Individuals who can know, express, and control their emotions will have no difficulty in having healthy communication while interacting with their environments. Communication is an indispensable necessity in our circles. Communication is an indispensable necessity in our circles as well as a high emotional intelligence about the maturity of self-recognition. Emotional intelligence represents the needs, impulses, and real values that guide one's behaviours, and determines one's relationships with people and success in working life (Güllüce \& İşcan, 2010).

Based on the theoretical and empirical literature on the relationship between emotional intelligence and communication skills, the hypothesis created for this study are presented below;

$\mathbf{H}_{1}$ : Emotional intelligence has a significant and positive effect on communication skills.

\section{METHOD OF STUDY}

This study aims to scrutinize the relationship between emotional intelligence and communication skills. While it is not easy to have good relations with all individuals, some people with communication skills are successful in establishing good relations with others and maintaining the relationships they have established. This suggests that people with good relationships may have high emotional intelligence. Therefore, the investigation of the relationship between emotional intelligence and communication skills will contribute to the literature significantly.

The universe of the research is healthcare workers of a private hospital in the Mediterranean Region. It has been learned that the number of healthcare workers is 243 . To determine the number of samples, "n= N.z2. $\sigma 2$ / (N-1). H2 + z2. 2 "” formula was used (Ural \& Kılıç, 2013). In this formula, N is the size of the universe; $n$ : sample size; $\sigma$ : standard deviation value; $\mathrm{H}$ : standard error value; $\mathrm{Z}$ : represents the theoretical value corresponding to a certain $\alpha$ significance level. For the universe value of 243 health workers, it was determined that the sample number to be examined in the study should be 149 health workers. A questionnaire was applied to 150 healthcare workers selected by simple random sampling method.

Besides the literature review, we used a survey in the study. Permission for this study was obtained from the Ethics Committee of Kahramanmaras Sutcu Imam University with the decision 
number 3 at the meeting dated 24/03/2021 and numbered 2021/18 of the relevant board.We created the conceptual framework of the survey technique with a literature review. We collected data from 150 people by using surveys. Then reliability, frequency, correlation, and regression analyses were performed using the SPSS statistical program. Finally, the findings were interpreted.

In this study, since the general attitude of emotional intelligence on communication skills was examined, the variables were subjected to one-dimensional analysis.

There are three parts in the survey. The first part includes the questions regarding the participants' demographic characteristics. In the second part, the Communication Skills Scale-Adult Form is used to measure participants' communication skills and the Emotional Intelligence Scale is used to measure the participants' emotional intelligence levels in the third part.

\subsection{Communication Skills Scale}

In the present study, we used the Communication Skills Scale-Adult Form (Korkut-Owen \& Demirbaş-Çelik, 2017), which consisted of 25 questions measuring five dimensions, to measure the participants' communication skills. We assessed communication skills using five items, coded 1= "never" to $5=$ "always." In line with the hypothesis established for this study, the use of a onedimensional general scale was preferred. The explained variance value of one dimension was found to be statistically sufficient (explained variance >0,500).

\subsection{Emotional Intelligence Scale (WLIES)}

The Wong and Law Emotional Intelligence Scale (Wong \& Law, 2002), which is made up of 16 questions measuring four dimensions, is used to measure the participants' emotional intelligence. It has 16 items on a 5-point Likert scale from 1 "strongly disagree" to 5 "strongly agree." In line with the hypothesis established for this study, the use of a one-dimensional general scale was preferred. The explained variance value of one dimension was found to be statistically sufficient (explained variance $>0,500)$.

\section{FINDINGS}

A total of 150 people participated in the current study. Table 1 shows the demographic information about the participants.

Table 1: Frequency Analysis of Demographic Characteristics of Participants

\begin{tabular}{|c|c|c|c|}
\hline Variable & & Frequency & Percent \\
\hline \multirow{6}{*}{ Age } & $18-25$ & 21 & 14,0 \\
\hline & $26-30$ & 24 & 16,0 \\
\hline & $31-35$ & 31 & 20,7 \\
\hline & $36-40$ & 15 & 10,0 \\
\hline & $41 \geq$ & 59 & 39,3 \\
\hline & Total & 150 & 100,0 \\
\hline \multirow{3}{*}{ Cender } & Male & 75 & 50,0 \\
\hline & Female & 75 & 50,0 \\
\hline & Total & 150 & 100,0 \\
\hline \multirow{3}{*}{ Marital Status } & Single & 45 & 30,0 \\
\hline & Married & 105 & 70,0 \\
\hline & Total & 150 & 100,0 \\
\hline \multirow{6}{*}{ Educational Status } & Primary Education & 6 & 4,0 \\
\hline & High School & 27 & 18,0 \\
\hline & Undergraduate & 91 & 60,7 \\
\hline & Master & 15 & 10,0 \\
\hline & Doctorate & 11 & 7,3 \\
\hline & Total & 150 & 100,0 \\
\hline \multirow{5}{*}{ Work Experience (as year) } & $>1$ & 12 & 8,0 \\
\hline & $1-5$ & 26 & 17,3 \\
\hline & $6-10$ & 37 & 24,7 \\
\hline & $10>$ & 75 & 50,0 \\
\hline & Total & 150 & 100,0 \\
\hline
\end{tabular}


In our study, Cronbach's alpha for communication skills was 0.940 and Cronbach's alpha for emotional intelligence was 0.872 . Cronbach's alpha demonstrated that the questionnaire was highly reliable. Nunnaly (1978) suggested 0.7 to be an acceptable reliability coefficient, however, sometimes the lower ones are also used in the literature.

Table 2: The Relationship between Emotional Intelligence and Communication Skills

\begin{tabular}{lcc}
\hline & Communication Skills & Emotional Intelligence \\
\hline Pearson Correlation & 1 &, $823^{* *}$ \\
\hline Sig. (2-tailed) & &, 000 \\
\hline $\mathbf{N}$ & 150 & 150 \\
\hline$* * p<0.01$ & &
\end{tabular}

As a result of Pearson's correlation analysis, which was used to find out whether there is a significant relationship between the perception of emotional intelligence and the communication skills of employees, it has been revealed that there is a positive and significant relationship between emotional intelligence and communication skills $(\mathrm{r}=0.823, \mathrm{p}<0.01)$. According to Table 2 , it can be said that if the employees' emotional intelligence increases, their communication skills will increase.

Table 3: Simple Linear Regression Analysis for Predicting Emotional Intelligence

\begin{tabular}{lccccccc}
\hline Variable & $\mathbf{B}$ & Std. Error & $\mathbf{B}$ & $\mathbf{R}^{\mathbf{2}}$ & $\mathbf{F}$ & $\mathbf{t}$ & $\mathbf{P}$ \\
\hline Emotional Intelligence &, 774 &, 044 &, 823 &, 68 & 309,609 & 17,596 &, 000 \\
\hline
\end{tabular}

The dependent variable: Communication Skills

Regression analysis has showed that emotional intelligence has a high and significant effect on communication skills $\left(\mathrm{R}=.82, \mathrm{R}^{2}=.68, \mathrm{p}<0.05\right)$. According to Table 3 , emotional intelligence accounted for $68 \%$ of the variance in communication skills.

\section{CONCLUSION}

Individuals, who can control their emotions, understand the emotions of other individuals, can clearly and precisely express themselves and understand what other people say by listening to them carefully for good communication. In this respect, the importance of emotional intelligence is increasing day by day. A person who knows himself/herself, is aware of his/her feelings and thoughts and knows his/her strengths and weaknesses (to be developed), can manage his/her own emotions, thoughts and behaviours and build positive and constructive interpersonal relations. An improved emotional intelligence with an ability to analyze and manage emotions as well as build healthy relationships are key to success in business, social, and private life. They will have a positive impact on developing and improving communication skills in groups in which individuals maintain their existence.

The results were interpreted making the analyses of reliability, frequency, correlation, and regression using the IBM SPSS 21.0 statistical software. As a result of the reliability analysis, Cronbach's alpha was found to be .940 and .872 for the variables of communication skills and emotional intelligence, respectively. These values suggest that the survey has high reliability. Pearson's correlation analysis was conducted to determine whether or not emotional intelligence perception was associated with the communication skills of employees. Accordingly, there was a positive and significant relationship between emotional intelligence perception and communication skills of the employees $(r=0.823, p<0.01)$. Besides, regression analysis was performed to determine whether emotional intelligence perception had an impact on their communication skills. Accordingly, emotional intelligence had an impact on communication skills $(\mathrm{p}<0.05$, beta $=.823)$. As a result, the model was found to be significant (Sig: .000, $\mathrm{R}^{2}=.68, \mathrm{~F}=309,609$ ), which supports other studies (e.g., Alaei, 2018; Amini et al., 2018; Barut, 2015; Büyükbeşe et al., 2017; Çetinkaya \& Alparslan, 2011; Ghasemi et al., 2018; Gül, 2017; Hendon et al., 2017; Jorfi, 2012; Lou \& Zhang, 2018; Petrovici \& Dobrescu, 2014; Taşliyan et al., 2017; Pelit et al., 2018; Yousefi, 2006). In order to generalize the results of the research, it is important to include samples of different hospital workers in future studies. In addition, it is seen that the organization of various activities that will increase the emotional intelligence of health workers is important for establishing healthier communication and increasing their communication skills. In this context, managers should work in this direction in their institutions. 
Ethics Statement: Permission for this study was obtained from the Ethics Committee of Kahramanmaras Sutcu Imam University with the decision number 3 at the meeting dated 24/03/2021 and numbered 2021/18 of the relevant board. In case of detection of a contrary situation, AKAD Journal has no responsibility and all responsibility belongs to the author of the study.

Etik Beyan: Bu çalışmada kullanılan anket yöntemi için Kahramanmaraş Sütçü İmam Üniversitesi Etik Kurulu'ndan 24/03/2021 tarihli ve 2021/18 nolu toplantisinda 3 sira sayll kararl ile izin alınmıştır. Aksi bir durumun tespiti halinde AKAD Dergisinin hiçbir sorumluluğu olmayıp, tüm sorumluluk çalışmanın yazar)ına aittir.

\section{REFERENCES}

Alaei, S. (2018). The relationship between emotional intelligence and communication skills in phd and master's degree students of Islamic Azad University. SBMU Journals Social Determinants of Health, 4(2), 100-104. https://doi.org/10.22037/sdh.v4i2.21762

Amini, M., Amini, M., Nabiee, P., \& Delavari, S. (2018). The relationship between emotional intelligence and communication skills in healthcare staff. Shiraz E Medical Journal, 20(4), 1-3. https://doi.org/10.5812/semj.80275

Anand, R., \& Udayasuriyan, G. (2010). Emotional intelligence and its relationship with leadership practices. International Journal of Business and Management, 5(2), 65-76. https://doi.org/10.5539/ijbm.v5n2p65

Aslan, S., \& Özata, M. (2008). Duygusal zekâ ve tükenmişlik arasındaki ilişkilerin araştırılması: Sağl1k çalışanları örneği. Erciyes Üniversitesi İktisadi ve İdari Bilimler Fakültesi Dergisi, 30, 77-97. https://dergipark.org.tr/tr/pub/erciyesiibd/issue/5887/77865

Barut, Y. (2015). The mediating role of organization culture on the relationship between emotional intelligence and communication skills: A sample of health employees who work in bozyak at raining research and city hospitals (Yayın No.425112) [Doktora Tezi, Yaşar Üniversitesi] Yüksek Öğretim Kurumu Tez https://tez.yok.gov.tr/UlusalTezMerkezi/tezSorguSonucYeni.jsp

Büyükbeşe, T., Direkçi, E., \& Erşahan, B. (2017). The impact of university students' emotional intelligence on communication skills and individual innovativeness levels. Kahramanmaraş Sütçü İmam Üniversitesi İktisadi ve İdari Bilimler Fakültesi Dergisi, 7(2), 321-336. http://iibfdergisi.ksu.edu.tr/tr/download/article-file/395666

Codier, E., Freitas, B., \& Muneno, L. (2013). Developing emotional intelligence ability in oncology nurses: A clinical rounds approach. Oncology Nursing Forum, 40(1), 22-29. https://doi.org/10.1188/13.ONF.22-29

Cole, M. L., Cox, J. D., \& Stavros, J. M. (2016). Building collaboration in team through emotional intelligence: Mediation by SOAR (strengths, opportunities, aspirations, and results). Journal of Management \& Organization, 25(2), 1-21. https://doi.org/10.1017/jmo.2016.43

Çakar, U., \& Arbak, Y. (2004). Emotional intelligence: The changing relationship of emotionintelligence under modern approaches. Dokuz Eylül Üniversitesi Sosyal Bilimler Enstitüsü Dergisi, 6(3), 23-48. https://acikerisim.deu.edu.tr/xmlui/handle/20.500.12397/5536

Çetinkaya, Ö., \& Alparslan, M. (2011). The effect of emotional intelligence on communication skills: An investigation on university students. Süleyman Demirel Üniversitesi İktisadi ve İdari Bilimler Fakültesi Dergisi, 16(1), 363-377. https://dergipark.org.tr/tr/download/article$\underline{\text { file/194529 }}$

Ghasemi, S., S., Olyaie, N., \& Shami, S. (2018). An investigation into the correlation between emotional intelligence and communication skills among nursing students. Indian Journal of Forensic Medicine \& Toxicology, 12(3), 178-183. https://doi.org/10.5958/09739130.2018.00155.X 
Goleman, D. (1995). Duygusal zeka neden IQ'dan daha önemlidir? (Çev.), B. S. Yüksel. Varlık Yayınları.

Goleman, D. (1998). Working with emotional intelligence. Bantam.

Gül, E. (2017). Relationship between emotional intelligence and communication skills: An application (Yayın No.490521) [Yüksek Lisans Tezi, Beykent Üniversitesi] Yüksek Öğretim Kurumu Tez Merkezi. https://tez.yok.gov.tr/UlusalTezMerkezi/tezSorguSonucYeni.jsp

Güllüce, A. Ç., \& İşcan, Ö. F. (2010). The relationship between occupational burnout and emotional intelligence. Eskişehir Osmangazi Üniversitesi İ̈BF Dergisi, 5(2), 7-29. https://dergipark.org.tr/tr/pub/oguiibf/issue/56495/785630

Hendon, M., Powell, L., \& Wimmer, H. (2017). Emotional intelligence and communication levels in information technology professionals. Science Direct Computers in Human Behavior, 71, 165171. https://doi.org/10.1016/j.chb.2017.01.048

Jadhav, T., \& Gupta, S. K. (2014). Global communication skills and its relationship with emotional intelligence. American Journal of Management, 14(4), 82-88. http://m.www.nabusinesspress.com/AJM/JadhavT Web14 4 .pdf

Jorfi, H. (2012). Management: A study of organizational culture and the relationship between emotional intelligence and communication effectiveness. Journal of Management Research, 4(1), 1-14. https://doi.org/10.5296/jmr.v4i1.936

Korkut, F. (2004). Okul temelli önleyici rehberlik ve psikolojik danışma. Anı Yayıncılık.

Korkut-Owen, F., \& Bugay, A. (2014). Developing a communication skills scale: Validity and reliability studies. Mersin Üniversitesi Eğitim Fakültesi Dergisi, 10(2), 51-64. https://app.trdizin.gov.tr/makale/TVRZNU56ZzRPQT09

Korkut-Owen, F., \& Demirbaş-Çelik, N. (2017). Yetişkinlerde kişilik özelliklerine göre iletişim. I. Uluslararası Akademik Çalışmalar Kongresi’nde Sözlü Sunulan Bildiri. https://www.inescongress.com

Lou, P., \& Zhang, L. (2018). Relationship between communication skills and emotional intelligence among medical students. 3rd Asia-Pacific Electronics and Electrical Engineering Conference (pp. 222-228).

Nunnaly, J. (1978). Psychometric theory. McGraw-Hill.

Özbek, A., \& Boztepe, Z. (2017). The relationship between emotional intelligence and organizational commitment with career expectations in business life: Primary school teachers health and social support fund. Kirlkkale Üniversitesi Sosyal Bilimler Dergisi, 7(1), 183-196. https://dergipark.org.tr/en/download/article-file/274034

Pelit, E., Karaçor, M., \&Kılıç, İ. (2018). The effect of emotional intelligence on communication skills: A study on tourism students. Dokuz Eylül Üniversitesi Sosyal Bilimler Enstitüsü Dergisi, 20(1), 85-107. https://dergipark.org.tr/tr/pub/deusosbil/issue/36903/279686

Petrovici, A., \& Dobrescu, T. (2014). The role of emotional intelligence in building interpersonal communication skills. Social and Behavioral Sciences, 116, 1405-1410. https://doi.org/10.1016/j.sbspro.2014.01.406

Rahim, M., Psenicka, C., Polychroniou, P., Zhao, J. H., Yu, C. S., Anita C. K., \& Ferdausy, S. (2002). A model of emotional intelligence and conflict management strategies: A study in seven countries. The International Journal of Organizational Analysis, 10(4), 302-326. https://doi.org/10.1108/eb028955

Saarni, C. (2001). Epilogue: Emotion communication and relationship context. International Journal of Behavioral Development, 25(2), 354-356. https://doi.org/10.1080/01650250143000094

Salovey, P., \& Mayer, J. D. (1990). Emotional intelligence. SAGE Journals Imagination, Cognition and Personality, 9(3), 185-211. https://doi.org/10.2190/DUGG-P24E-52WK-6CDG 
Swarnalatha, C., \& Sureshkrishna, G. (2013). Emotional intelligence and job satisfaction: A study among employees of automotive industries in India. International Business Management, 7(1), 46-49. http://docsdrive.com/pdfs/medwelljournals/ibm/2013/46-49.pdf

Şen-Demir, Ş., \& Demir, M. (2009). The role of emotional intelligence in organizational communication: A research in hospitality enterprises. Selçuk İletişim 6(1), 67-77. https://dergipark.org.tr/tr/download/article-file/177855

Taşlıyan, M., Hırlak, B., \& Harbalığlu, M. (2017). The relationship between emotional intelligence, communication skills and academic achievement: An application on university students. Assam Uluslararası Hakemli Dergi, 4 2(3), https://dergipark.org.tr/tr/pub/assam/issue/32282/358459

Tuğrul, C. (1999). Duygusal zeka. Klinik Psikiyatri, 1, 12-20. https://jag.journalagent.com/kpd/pdfs/KPD 2 2 11 12 20 20.pdf

Tutar, H., \& Yılmaz, M. K. (2003). Genel iletişim. Nobel Yayıncılık.

Türken, H., Begüm, E. S., \& Çalım, S. İ. (2016). Öğrenci ebelerin duygusal zekaları ile iletişim becerileri arasındaki ilişki. Celal Bayar Üniversitesi Sağlık Bilimleri Enstitüsü Dergisi, 3(4), 447-452. https://dergipark.org.tr/en/download/article-file/261506

Ural, A., \& Kılıç, İ. (2013). Bilimsel araştırma süreci ve SPSS ile veri analizi. Detay Yayıncılık.

Weisinger, H. (1998). Emotional intelligence at work. Jossey-Bass.

Wong, C., \& Law, K. S. (2002). The effects of leader and follower emotion intelligence on performance and attitude: An exploratory study. The Leadership Quarterly, 13(3), 243-274. https://doi.org/10.1016/S1048-9843(02)00099-1

Yousefi, F. (2006). The relationship between emotional intelligence and communication skills in university students. Journal of Iranian Psychologists, 3(9), 5-13. https://www.sid.ir/en/journal/ViewPaper.aspx?id=10312 